\title{
PUTTING VOLUNTARINESS BACK INTO AUTOMATISM
}

\author{
Stanley Yeo*
}

This article challenges the common law principles governing the concept of involuntariness and its subset, automatism. It argues that the courts have misconceived the concept as having to do with unconsciousness and its derivatives, deliberation and intention. In their place, involuntariness should be defined in terms of lack of control in the sense of a total inability to contain one's actions. Such a definition will do much to clarify the confusing state of the current law, especially in relation to cases of insane automatism.

\section{INTRODUCTION}

A cardinal principle of the criminal law, both here and elsewhere, is that a person should not be convicted and punished for something done by her or him involuntarily. ${ }^{1}$ Yet, an accurate and comprehensible definition of involuntariness has thus far eluded both the courts and law reform bodies which have considered the concept. Noting this, the Casey Committee recommended against introducing a provision on involuntariness in the Crimes Bill 1989, being content to state that in the absence of such a provision, "the courts will continue to apply relatively well-settled common law principles". ${ }^{2}$ This is a highly unsatisfactory state of affairs. The simple existence of principles that are "wellsettled" does not make for a sound definition of involuntariness. Worse still, the correctness of these principles can be seriously challenged. I shall do so by critiquing case authorities on automatism, which is a specific type of involuntariness. My justification

* Professor, School of Law and Justice, Southern Cross University, NSW, Australia. Visiting lecturer in criminal law at the Faculty of Law, Victoria University of Wellington, Spring 2000. I wish to thank my colleagues Austin Punch, Emma Sutcliffe and Nicholas Wood for their helpful comments on an earlier draft of this article. All errors are mine alone.

1 Kilbride $v$ Lake [1962] NZLR 590, 593 (CA) per Woodhouse J. Conventional examples of involuntariness are unwilled muscular contractions like a reflex, spasm or convulsion, and conduct done while asleep or unconscious.

2 Report of the Crimes Consultative Committee on the Crimes Bill 1989 (Department of Justice, Wellington, 1991) 12 chaired by Justice Casey. 
for selecting these cases for attention is that the vast majority of common law principles on involuntariness have originated from them.

My discussion begins by stating in bare terms what I believe to be two significant judicial misconceptions regarding automatism. This will be followed by my understanding of the true nature of automatism with suggestions as to how the judicial misconceptions might be rectified to accord with this. I shall then support my contentions by presenting possible explanations for the judicial misconceptions and by evaluating some of the leading New Zealand cases on the subject.

\section{JUDICIAL MISCONCEPTIONS CONCERNING AUTOMATISM}

The first judicial misconception concerning automatism (and consequently, involuntariness) is that it consists of a state of unconsciousness or impaired consciousness. This misconception stems directly from the view that the plea of automatism involves a claim by the defendant that her or his act was not deliberate or purposeful. The judicial thinking here is that persons have to be at least partly conscious in order to deliberately perform an act. In the words of North P in the Court of Appeal case of $R v$ Burr: ${ }^{3}$

In my opinion then there is now clear judicial authority for the view that in order for a defence of automatism to succeed, the person whose conduct is under review must be unconscious of what he was doing. In short that what he did was an unconscious involuntary act ... [T]he evidence must be sufficient to lay a proper foundation for the plea that the accused person acted through his body without the assistance of his mind, in the sense that he was not able to make the necessary decisions and to determine whether or not to do the act ... [A]ll the deliberative functions of the mind must be absent so that the accused person acts automatically.

Although later cases have been less firm about the need for unconsciousness, it continues to have a pivotal role in the determination of automatism. Thus, in the Court of Appeal case of $R v$ Campbell, it was held that a person is in an automatic state who is "acting involuntarily in the sense that his actions are independent of his will, and therefore not subject to any conscious control". ${ }^{4}$ From there, it is but a short step for the judges to regard the plea of automatism as negating the criminal intention required for the particular crime under consideration. For instance, Gresson P in the Court of Appeal

$3 \quad R v$ Burr [1969] NZLR 736, 744-745 (CA), after referring to the New Zealand case of $R v$ Cottle [1958] NZLR 999 (CA) and the House of Lords case of Bratty $v$ Attorney-General for Northern Ireland [1963] AC 386 (HL).

$4 \quad R$ v Campbell (1997) 15 CRNZ 138, 146 (CA) per Tompkins J (emphasis added). 
case of $R v$ Cottle held that the plea of automatism "may be operative in so far as it prevents adequate proof by the prosecution of intent". 5

The second judicial misconception concerning automatism is that automatic states caused by a disease of the mind must be dealt with as the defence of insanity specified in section 23 of the Crimes Act 1961. ${ }^{6}$ The law does not recognise a defence of insane automatism existing outside of section 23. To cite North P in Burr again: ${ }^{7}$

It would be quite contrary to the view the law has always adopted in the case of an insane person for he is liable unless he is able to meet the tests laid down in the M'Naghten rules, which ... are now enshrined in our Crimes Act.

In the same vein, in the more recent High Court case of Burnskey $v$ Police, Temm J observed that: ${ }^{8}$

All three judges in Cottle [referred to previously] made it clear that if an accused put forward a defence of automatism which was based upon a disease of the mind then the Judge ought to put to the jury the question as to whether the proper verdict was not guilty by reason of insanity.

$5 \quad R v$ Cottle [1958] NZLR 999, 1021 (CA) and relied upon in $R v$ Bannin [1991] 2 NZLR 237, 243 (HC) Note also the following comment by G Orchard Crimes Update (New Zealand Law Society Seminar, Wellington, 1990) 42-43 that:

When the only crime in question requires awareness of essential circumstances or an intention to cause a particular result, a state of impaired consciousness which might arguably constitute automatism might preclude a finding of the requisite mens rea, in which case there will be no need to decide whether the conduct was voluntary. In such a case an adequate direction on the evidence and the need for the requisite 'intention' should mean that a further direction on the need for a 'voluntary' or 'willed' act will not be necessary, for proof of the former will involve proof of the latter.

6 The relevant part of which is s 23(2) which reads:

No person shall be convicted of an offence by reason of an act done or omitted by him when labouring under natural imbecility or disease of the mind to such an extent as to render him incapable -

Of understanding the nature and quality of the act or omission; or

Of knowing that the act or omission was morally wrong, having regard to the commonly accepted standards of right and wrong.

$7 \quad R v$ Burr [1969] NZLR 736, 745 (CA).

8 Burnskey v Police (1992) 8 CRNZ 582, 589 (HC). 
Having identified these judicial misconceptions, I shall now explain why they are misguided in their understanding of the concept of automatism and, consequently, of involuntariness.

\section{SETTING THE LAW RIGHT}

The first judicial misconception comprises making unconsciousness or impaired consciousness the primary feature of an automatic state when the correct legal position is that it involves the total inability to control one's conduct. By "control" is meant an inability to contain or restrain oneself. Barwick CJ in the High Court of Australia case of Ryan $v$ The Queen expressed the matter thus: ${ }^{9}$

[I]t is important ... not to regard [automatism] as of the essence of the discussion, however convenient an expression automatism may be to comprehend involuntary deeds where the lack of concomitant or controlling will to act is due to diverse causes. It is that lack of will which is the relevant determinant ... It is of course the absence of the will to act or, perhaps, more precisely, of its exercise rather than lack of knowledge or consciousness which ... decides criminal liability.

Under this view of automatism, people can exercise their deliberative functions of the mind and at the same time be incapable of controlling their actions. The classic example is a person who has been so provoked as to go completely berserk. Hence, when deciding a murder case involving the defence of provocation, Gleeson CJ in the New South Wales Court of Criminal Appeal case of $R v$ Chhay noted that: ${ }^{10}$

[T] he kind of loss of self-control that is here in question is not something that results in a state of automatism ... [The] fact [is] that we are not dealing with absolute loss of self-control.

Persons acting while in an automatic state may be fully conscious of what they are doing and intend the consequences of their actions while lacking any mental capacity whatsoever to restrain themselves. In the words of Thomas J in the Queensland Court of Criminal Appeal case of $R v$ Milloy, for automatism to succeed, "impairment of relevant capacities as distinct from total deprivation of these capacities [will not suffice] ... it is

9 Ryan $v$ The Queen (1967) 121 CLR 205, 214. See also the recent Supreme Court of Canada decision in Stone $v$ The Queen (1999) 134 CCC (3d) 353, 421 (SCC) where Bastarache J said that "voluntariness, rather than consciousness, is the key legal element of automatic behaviour since the defence of automatism amounts to a denial of the voluntariness component of the actus reus".

$10 R v$ Chhay (1994) 72 A Crim R 1, 8 (CA NSW). 
fundamental to a defence of automatism that the actor has no control over his actions."11 This condition may be described as a particularly severe form of irresistible impulse. ${ }^{12}$

Viewed in this way, a state of unconsciousness or impaired consciousness may point to a defendant's inability to contain their conduct, but such a state is not essential for automatism to exist. ${ }^{13}$ The correct emphasis on containment rather than consciousness is succinctly expressed in the following comment by Michael Coles, a forensic psychologist: ${ }^{14}$

$[\mathrm{O}] \mathrm{n}$ the basis of the available knowledge of human behaviour, it may be suggested that many of the crimes the courts have decided were committed in an automatic state - that is, in the absence of conscious, volitional control, or while the mind was a total blank - actually may have occurred in a state of diminished consciousness, with the diminished consciousness resulting in the diminished conscious control of behaviour. In other words, the individual becomes disinhibited, and behaviour that the individual would otherwise be able to [contain] gains expression.

Besides the scientific support for this definition of automatism, it is also consistent with the following oft-cited pronouncement by Lord Denning in the House of Lords case of Bratty $v$ Attorney-General for Northern Ireland: ${ }^{15}$

No act is punishable if it is done involuntarily: and an involuntary act in this context - some people nowadays prefer to speak of it as 'automatism' - means an act which is done by the muscles without any control by the mind, such as a spasm, a reflex action or a convulsion; or an act done by a person who is not conscious of what he is doing, such as an act done whilst suffering from a concussion or whilst sleepwalking.

$11 R v$ Milloy (1991) 54 A Crim R 340, 342-343 (CA NSW) (Original emphases).

12 A good example of this is compulsive mania and its element of akrasia, namely, of acting against one's better judgment: see further F McAuley and P McCutcheon Criminal Liability: A Grammar (Roundhall Sweet and Maxwell, Dublin, 2000) 670-671.

13 This stance is taken by the English Law Commission A Criminal Code for England and Wales (Law Com No 177, London, 1989). Clause 33(1) of its draft Criminal Code provides that:

A person is not guilty of an offence if - (a) he acts in a state of automatism, that is, his act (ii) occurs while he is in a condition (whether of sleep, unconsciousness, impaired consciousness or otherwise) depriving him of effective control of his act ...

14 "Scientific Support for the Legal Concept of Automatism" (2000) 7 Psychiatry, Psychology and Law 33, 37 (Original emphasis). The word "contain" in parenthesis replaces the word "control" which Coles, in personal correspondence with me, says is not as precise in its meaning as "contain" in the context of my discussion.

15 Bratty v Attorney-General for Northern Ireland [1963] AC 386, 409 (HL). 
In this passage, Lord Denning provides two categories of cases which he regards as being automatic. He describes the first category as involving an absence of any control of the mind over one's actions. As has been recognised by later decisions, this category covers actors who may have been conscious of what they were doing but who could not contain their actions. Lord Denning describes the second category of cases as involving a lack of consciousness. Yet, in respect of the examples of concussion and sleepwalking which he provides for this category, one can envisage apparently deliberate or goaldirected conduct performed by the defendant while concussed or in a state of sleepwalking. For instance, in the English case of $R v T^{16}$ the defendant was regarded as being in an automatic state when she committed an armed robbery which involved stabbing her victim and leaning into the victim's car to take her bag. The medical evidence supporting this mental state was that she was suffering from post-traumatic stress disorder after having been raped three days earlier. Such a disorder is closely similar in effect to that of concussion caused by a physical blow. ${ }^{17}$ As for sleepwalking, the Canadian case of $R v$ Parks $^{18}$ exemplifies the judicial willingness to regard a sleepwalker as behaving in an automatic state even though he had performed apparently goal-directed conduct such as driving a car to the house of his victims, going to their bedroom and stabbing them to death in their beds. The point made here is that the key component of the two categories of cases identified by Lord Denning in Bratty is a defendant's inability to contain their behaviour and not, as our courts have ruled, the loss or impairment of the conscious or deliberative functions of the mind. ${ }^{19}$

In their textbook Principles of Criminal Law, Andrew Simester and Warren Brookbanks regard as correct North P's statement in Burr that "all the deliberative functions of the mind must be absent so that the accused person acts automatically". ${ }^{20}$ The authors contend that, "what counts is the inability deliberatively to control one's conduct - that one's movements are not responsive to a capacity to reason and deliberate about one's conduct". ${ }^{21}$ In view of the preceding discussion, their emphasis on deliberation is misplaced. Also, the fact that they have introduced the notion of "control" when North P

$16 R v T[1990]$ Crim LR 256.

17 See also $R v$ Rabey (1981) 54 CCC (2d) 1, 15 (SCC).

$18 R v$ Parks (1990) 56 CCC (3d) 449 (CA Ont).

19 Significantly, North P in R v Burr [1969] NZLR 736, 744 (CA) relied heavily on the passage by Lord Denning in Bratty which he described as "particularly informative" when expressing his views on automatism. With respect, those views show that he misunderstood the passage.

20 Andrew Simster and Warren Brookbanks Principles of Criminal Law (Brooker's, Wellington, 1998) 70 citing $R$ v Burr [1969] NZLR 736, 745 (CA).

21 Simster and Brookbanks, above n 20 (Original emphasis). 
said nothing about such a notion suggests a sub-conscious acknowledgement of control as the fundamental element in automatism.

The second judicial misconception flows directly from the first. In describing the concept of automatism in terms of conduct which was done unconsciously, without deliberation or without intention, the courts have thereby brought it within the fold of the defence of insanity under section 23 of the Crimes Act 1961. This is because such a description of automatism accords with that part of the section which reads, "incapable of understanding the nature and quality of the act or omission". ${ }^{22}$ Having taken this view, the courts have not concerned themselves with the further possibility that there might be cases of insane automatism which fall outside the provision. Were the courts to regard automatism as involving an inability to contain one's actions, as has been suggested above, they would then have to find a way of providing the special verdict ${ }^{23}$ to those defendants who were suffering from a disease of the mind which rendered them totally incapable of containing their actions but who nevertheless understood the nature and quality of those actions. It is submitted that such a way is readily provided for by resorting to the residual common law defence provision under section 20 of the Crimes Act $1961 .^{24}$ Since these types of cases should properly be treated as cases of insanity and because section 23 , as presently worded, does not cater for them, a very strong argument can be made for invoking section 20 on account that it is both practical and just to do so. ${ }^{25}$ As for the requirement under section 20 that common law defences apply "except so far as they are altered by or are inconsistent with this Act or any other enactment" I would contend that section 23 does not purport to be an exhaustive pronouncement of the insanity defence. Since cases of insanity involving lack of control are not dealt with by section 23 , such cases cannot be inconsistent with that provision.

At this juncture one might ask, given that my definition of automatism is a type of irresistible impulse, what of the many case authorities which have categorically rejected

22 See s 23(2)(a), above $\mathrm{n} 6$.

23 By which is meant a verdict of not guilty by reason of insanity, sometimes also referred to as a qualified acquittal.

24 The relevant part of which is s 20(1) which reads:

All rules and principles of the common law which render any circumstances a justification or excuse for any act or omission, or a defence to any charge, shall remain in force and apply in respect of a charge of any offence, whether under this Act or under any other enactment, except so far as they are altered by or are inconsistent with this Act or any other enactment.

25 See $R v$ Kingston [1994] 3 WLR 519, 536 (HL) per Lord Mustill; $R v$ Cargill [1995] 3 NZLR 263, 268 (CA) per Richardson J. 
this type of mental incapacity as satisfying the insanity defence? My response is that all these case authorities were solely concerned with whether irresistible impulse fell within the definition of insanity under the M'Naghten Rules or their statutory equivalent. The courts were not asked to consider whether irresistible impulse could constitute a form of insanity lying outside those rules or statutory provision. All this is borne out in the following comment by Lord Denning in Bratty: ${ }^{26}$

When a man is charged with murder, and it appears that he knew what he was doing, but that he could not resist it, then his assertion 'I couldn't help myself' is no defence in itself ... it does not render his act involuntary so as to entitle him to an unqualified acquittal.

Lord Denning was correct in observing that the M'Naghten Rules would not cover such a case in view of the defendant's understanding of the nature and quality of her or his act. His Lordship was likewise correct in rejecting the defence submission in Bratty that there was a common law defence of involuntariness based on irresistible impulse which resulted in an unqualified acquittal. But his Lordship was not invited to, nor did he, consider whether there was such a defence which resulted in the special verdict. ${ }^{27}$

In contrast, the Supreme Court of Ireland was asked to consider just such a type of defence of insanity in Doyle $v$ Wicklow County Council. ${ }^{28}$ Griffin J, who delivered the main judgment, began by noting that the M'Naghten Rules consisted of answers to specific questions put to the House of Lords which were limited to the effect of insane delusions on a defendant's knowledge. ${ }^{29}$ Consequently, the rules did not provide the exclusive test $^{30}$ for determining a defendant's sanity or insanity, leaving Griffin J to consider other types of insanity recognised by the medical sciences. He did so by regarding the following passage from an earlier Irish decision as correctly stating the law on the matter: ${ }^{31}$

26 Bratty $v$ Attorney-General for Northern Ireland [1963] AC 386, 409 (HL).

27 This qualification is equally applicable to McCarthy J's rejection in R $v$ Burr [1969] NZLR 736, 750751 (CA) of irresistible impulse as supporting a plea of insanity under s 23 of the Crimes Act.

28 Doyle v Wicklow County Council [1974] IR 55 (SC Ir).

29 Doyle v Wicklow County Council, above n 28, 70, and agreed to by all four other judges.

30 For a similar view, see JF Stephen Digest of Criminal Law (4 ed, Macmillan and Co, London, 1887) 155 onwards, citing Oxford's case (1840) 9 Car \& P 525; 173 ER 941 in support of his view that at common law a person was not criminally responsible for conduct which he or she was prevented from controlling as a result of mental disease.

31 Doyle $v$ Wicklow County Council, above n 28, 71, citing Henchy J in The People (Attorney General) v Hayes (20 November 1967) Central Criminal Court. 
In the normal case, tried in accordance with the McNaghten [sic] rules, the test is solely one of knowledge: did he know the nature and quality of his act or did he know that the act was wrong? The rules do not take into account the capacity of a man on the basis of his knowledge to act or to refrain from acting, and I believe it to be correct psychiatric science to acccept that certain serious mental diseases, enable a man to understand the morality or immorality of his act or the legality or illegality of it or the nature of it, but nevertheless prevent him from exercising a free volition as to whether he should or should not do that act ...

The symmetry which this passage perceives between a defendant's "capacity to act or refrain from acting", and "exercising a free volition", is particularly forceful. ${ }^{32}$

To summarise, my contention is that under New Zealand law a defendant could be found not guilty by reason of insanity and disposed of procedurally under section 115 of the Criminal Justice Act $1985,{ }^{33}$ if, at the time of the alleged offence, the defendant was (1) suffering from a disease of the mind which (2) rendered her or him totally incapable of containing her or his actions. The first condition makes the case one of insanity (albeit not the type covered by section 23 , since the defendant understood the nature and quality of the act), while the second condition makes it one of automatism. Such a form of insane automatism should properly be recognised as a residual common law defence which operates comfortably alongside the statutory defence of insanity.

\section{POSSIBLE EXPLANATIONS FOR THE MISCONCEPTIONS}

Identifying the possible explanations as to why the courts engaged in the abovementioned misconceptions will help to ensure that they do not happen again. The exercise will also assist with the analysis of some of the leading New Zealand cases to be conducted in the next part.

One likely explanation for the misconceptions is that they were the judicial responses to specific submissions by defence counsel. These submissions presented the issues of automatism and insanity in such a way as to give rise to the misconceptions. For instance, in respect of the first misconception concerning the nature of automatism, the defence may have argued that automatism negated the criminal intent or mens rea required to be proven for the crime in question. This argument may have led the judges to engage in a discourse on automatism in terms of consciousness or deliberateness.

32 McAuley and McCutcheon, above $\mathrm{n}$ 12, 662-666, who contend that the fact that a person is "determined to do something does not entail, and may exclude, the conclusion that he was unable to refrain from doing it". I would argue that determination does not prove an inability to control one's impulse.

33 This section does not require amending to accommodate a common law defence of insane automatism because it is not "s 23 specific" but provides simply that cases in which a person "is acquitted on account of his or her insanity" fall within its ambit. 
Conceivably, had the defence instead contended that automatism negated the voluntariness component or actus reus of the crime in question, the judges would then have viewed automatism correctly as involving a total incapacity to contain one's actions.

Similarly, with regard to the second misconception of confining insane automatism to the section 23 defence, this may have been the direct result of defence counsel's seeking to bring the case outside that defence in order to secure an unqualified acquittal. In finding unacceptable such an outcome, the judges confined themselves entirely to the wording of the defence provision. They may have been prepared to look beyond section 23 had the defence sought instead the special verdict by virtue of section 20 .

Another possible explanation for the misconceptions is that the concept of automatism has often been discussed by judges in close association with the defence of insanity as specified by the M'Naghten Rules or their statutory equivalent. Since that defence is concerned with cognitive defects (that is, defects of understanding or of knowledge) it is entirely understandable that the judges chose to make consciousness or deliberateness the primary determinant of whether a defendant was suffering from an automatic condition. In doing so, they lost sight of the fact that automatism is a subset of involuntariness and therefore constitutes a volitional defect as opposed to a cognitive one. Had the judges appreciated this, they may well have proceeded to recognise a plea of insane automatism falling outside the ambit of the $M^{\prime}$ Naghten Rules or their statutory equivalent.

A third possible explanation for the misconceptions is that they may have been caused by unwarranted and uncritical reliance by judges on expert testimony concerning the nature of automatism. This is clearly illustrated in cases of automatism coming before the courts which have involved states of dissociation. Dissociation is a medical concept, not a legal one. The description of dissociation by the American Psychiatric Association as "a disruption in the usually integrated functions of consciousness, memory, identity, or perception of the environment" 34 shows the emphasis by medical science on cognition rather than on volition. Unfortunately, trial judges have often allowed this description of dissociation by expert witnesses as proof of automatism. For example, in $R v$ Arnold, the Court of Appeal referred without question to expert opinion that "total dissociation" amounted to automatism. ${ }^{35}$ The correct position is that expert witnesses should not be permitted to express their views about the nature of automatism since that would be

34 Diagnostic and Statistical Manual of Mental Disorders (4 ed, APA, Washington DC, 1994) 477.

$35 R v$ Arnold [1985] 1 NZLR 193, 195 (CA) per McMullin J. 
usurping the role of the trial judge. As has been pointedly expressed by Professor Glanville Williams: ${ }^{36}$

Because automatism is a legal concept, a psychiatrist should be asked to testify to the mental condition as psychiatrically recognised, not to 'automatism'. It is for the judge to make the translation.

One or more of these possible explanations for the judicial misconceptions concerning automatism will have occurred in each of the New Zealand decisions to be discussed below.

\section{SELECTED CASE STUDIES}

Three cases have been selected for analysis for the purpose of revealing the above mentioned judicial misconceptions, the way they may have come about and the outcomes had the courts understood and applied the law correctly.

The first case is $R v$ Burr, $^{37}$ a leading early decision of the Court of Appeal which has been relied upon in subsequent cases. The appellant (D) was convicted of murdering the victim (V) who had lent him some money. At the time of the killing, D was in a harrassed mental state on account of his business difficulties and domestic problems between his wife and his mother. When $\mathrm{D}$ informed $\mathrm{V}$ that he could not meet payment of the loan by the due date, V's attitude toward him changed which in turn made D hate V. $\mathrm{D}$ then effected a plan to kill $\mathrm{V}$ which he carried out successfully. At his trial, expert evidence revealed that when he fatally shot $\mathrm{V}, \mathrm{D}$ knew what he was doing and that it was morally wrong. His counsel submitted that, at the time of the killing, D was suffering from a disease of the mind which "left him no choice" but to kill V and that this established that D's conduct was involuntary. ${ }^{38}$ The defence counsel went on to contend that without volition there could be no intention necessary for the crime of murder. Since D knew what he was doing and that it was morally wrong, he did not come within the plea of insanity. Accordingly, he should receive an unqualified acquittal by reason of sane automatism.

36 G Williams Textbook of Criminal Law (Stevens, London, 1978) and cited in the Supreme Court of Canada case of $R v$ Rabey (1981) 54 CCC (2d) 1, 30. Contrast S Yeo "Clarifying Automatism" 25(1) International Journal of Law and Psychiatry (forthcoming) for the suggestion that in future trial judges should insist that expert evidence of automatism show that the defendant suffered a defect of volition rather than the defect of consciousness which the experts are presently inclined to do based on their scientific disciplines.

$37 \quad R v$ Burr [1969] NZLR 736 (CA).

$38 R$ v Burr, above $\mathrm{n} 37,746$. 
In the leading judgment, North $\mathrm{P}$ rejected the defence arguments in the following terms: ${ }^{39}$

[I]n my opinion, the evidence must be sufficient to lay a proper foundation for the plea [of automatism] that the accused person acted through his body and without assistance of his mind, in the sense that he was not able to make the necessary decisions and to determine whether or not to do the act. Now in the present case all the facts show that the appellant knew what he was doing and knew that what he was doing was wrong. This being so, in my view there was no room at all for the defence of automatism.

This passage shows how North P may have been influenced by the defence argument that automatism negated criminal intention. His Honour's description of automatism as involving an inability to make decisions and to determine whether to do the act is closely associated with a lack of intention. Furthermore, the weight he gives to D's knowledge of what he was doing and that it was wrong likewise bears on the concept of intention. Having arrived at this description of automatism, it is fully understandable why North P went on to hold that D's inability to control his urge to kill $\mathrm{V}$ had nothing at all to do with automatism. ${ }^{40}$

North P's reference to D's knowledge of what he was doing and that it was wrong also shows how closely he related the concept of automatism to the defence of insanity as specified under section 23. ${ }^{41}$ Earlier in his judgment, his Honour had regarded all cases of insanity, including insane automatism, as falling within that statutory provision. Since $\mathrm{D}$ did not satisfy the requirement under section 23 of a lack of knowledge of what he was doing or that it was wrong, neither automatism nor insanity could be relied upon. Accordingly, D was properly convicted of murder.

Rectification of the judicial misconceptions contained in North P's judgment could have produced the following outcomes. First, the court would have paid much closer attention to the expert testimony that $\mathrm{D}$ "was no longer under full voluntary control of his actions", and that he "was compelled by an irresistible motivation to do what he did". 42 This evidence, rather than evidence as to D's deliberative functions and knowledge about his act and its wrongness, would have provided the foundation for automatism. Secondly, the court may have been more prepared to accept the defence arguments if the defence counsel had sought not an unqualified acquittal, but a special

$39 R$ R Burr, above n 37, 744-745.

$40 R$ v Burr, above $\mathrm{n} 37,745$.

$41 R$ v Burr, above $\mathrm{n} 37,743$.

$42 R$ v Burr, above n $37,749$. 
verdict based on a common law defence of insane automatism (as opposed to the defence under section 23). Applying these outcomes to the facts in Burr, the result would probably have been the same as the one reached by the court. This is because the expert evidence indicated that, despite his urge to kill $\mathrm{V}$, D retained a degree of ability to contain his acts. In the words of North $\mathrm{P}$, "he nevertheless possessed the ability to say 'no'". ${ }^{43}$ For $\mathrm{D}$ to have been in an automatic state, he needed to have completely lacked such an ability to contain or restrain himself.

The second case, $R v$ Campbell, ${ }^{44}$ has been selected because it is the most recent decision of the Court of Appeal on automatism. The appellant (D) was charged with murder and convicted of manslaughter. Evidence was tendered that D was suffering from post-traumatic stress disorder when he killed the victim $(\mathrm{V})$. This disorder was traceable to D's having been badly scalded when he was three years old with the resulting physical scarring greatly embarrassing him during his school years. Additionally, D had been sexually abused as a child by an adult male family friend. On the day of the killing, D had visited V, a friend of his parents', at V's home. D said that V had put his hand on D's thigh and smiled at him in the same way as his childhood sexual abuser. This caused D to lose all control over his murderous assault on V, consisting of beating him with a poker and his fists and later striking him with an axe. At the trial, the defence counsel recognised that the evidence did not support a plea of automatism because $\mathrm{D}$ did not comply with the test of automatism laid down in Cottle and Bratty, namely, a lack of consciousness. The defence counsel also conceded that the plea of insanity under section 23 was inapplicable because D knew the nature and quality of his acts. Counsel then submitted that there was evidence that D had acted involuntarily "in the sense that he was incapable of exercising any voluntary control over his acts", 45 and that this warranted an unqualified acquittal. The trial judge refused to leave this defence to the jury with the result that $\mathrm{D}$ was convicted of manslaughter either because the prosecution had not proven the necessary murderous intent or had not excluded provocation. On appeal, D argued that the trial judge had erred in ruling that the defence advanced by the defence counsel could not be put to the jury.

Tompkins J, who delivered the judgment of the Court of Appeal, dismissed the appeal in the following terms: ${ }^{46}$

\footnotetext{
$43 R$ v Burr, above n 37, 745.

$44 \quad R v$ Campbell (1997) 15 CRNZ 138 (CA).

$45 \mathrm{R} v$ Campbell, above $\mathrm{n} 44,143$.

$46 R v$ Campbell, above n 44, 146.
} 
There is no third category [of defence] of the kind proposed by [the defence counsel]. If a person is acting involuntarily in the sense that his actions are independent of his will and are therefore not subject to any conscious control, it can only be insane or sane automatism. It is insane automatism where he is legally insane within the meaning of section 23 of the Crimes Act 1961. It is sane automatism if he lacks the ability to control his actions because of the operation of some outside events on a sound mind ... but is not suffering from a disease of the mind within section 23. But if his conduct is not within the boundaries of automatism, and he is not legally insane within section 23 , he is legally responsible for his acts, save only, in the case of murder, to a defence of provocation reducing murder to manslaughter.

Earlier in his judgment, Tompkins $\mathrm{J}$ had expressly rejected the requirement of consciousness for automatism as had been suggested in earlier decisions such as Cottle, Bratty and Burr. ${ }^{47}$ However, in the above passage, Tompkins J has continued to include consciousness in his definition of automatism. His need to do so becomes evident when, towards the close of his judgment, he noted that D "was not only aware of his actions, but also they were his deliberate voluntary acts". ${ }^{48}$ This juxtaposition of the descriptors "conscious" and "deliberate", with the words "control" and "voluntary" strongly suggests that Tompkins J was continuing to view automatism in terms of consciousness and deliberation rather than according to its true nature of involuntariness and a total lack of containment. Hence the perpetuation of the first type of judicial misconception. As for the second misconception, this is evident in the above-quoted passage from Tompkins J's judgment where he confines cases of insane automatism to the operation of section 23 alone.

Rectifying these misconceptions could have produced the following outcomes. First, the court would have given greater weight to the expert evidence that $\mathrm{D}$ did not have any control of his actions during a period of flashback to the scalding and sexual abuse experienced by him as a child. ${ }^{49}$ In this respect, what the defence counsel should have contended was that such evidence did support a finding of an automatic state rather than conceding that it did not. Secondly, the court could have gone on to find that D's automatic state was caused by a disease of the mind (namely, post-traumatic stress syndrome) but that his case did not come within section 23 because he knew what he was doing and that it was wrong. Consequently, D's type of insane automatism should be covered under a common law defence recognised by section 20 of the Crimes Act with the result that $\mathrm{D}$ would receive the special verdict. It would appear that the court's

$47 \quad R v$ Campbell, above n 44, 143-144.

$48 R v$ Campbell, above $\mathrm{n} 44,146$.

49 See the opinions of Professor AHW Taylor and Dr Brinded as described in Tompkins J's judgment at 141-142. 
rejection of the defence contentions was because it was loath to permit an unqualified acquittal as sought by the defence. Had the defence sought the special verdict instead, the court may have had far less hesitation in finding that D had experienced an automatic state at the time of killing, and gone on to invoke section 20 to achieve this result.

Regarding the court's comment in the quoted passage concerning the defence of provocation, it is submitted that this only describes those cases where the defendant's loss of self-control is less than complete. As one judge has observed, there is an "intermediate stage between icy detachment and going berserk", 50 and it is only at this intermediate stage that the defence of provocation applies. Where the loss of self-control is total, the proper plea is automatism, not provocation. ${ }^{51}$ This explains the different outcomes of successful pleas of provocation and automatism. For provocation, there is no complete acquittal because the defendant had "retained some control, albeit insufficient to resist the emotional impulse" such that the defendant "may still be blamed for not in fact resisting." 52 Where the defendant had gone berserk so as to lack control completely, he or she cannot be blamed at all for not resisting. This describes an automatic state which can exist even where the defendant may have been partially conscious and deliberative of what he or she was doing. The descriptor "irresistible impulse" accurately identifies the essence of this state of inability to contain one's acts which may co-exist with an ability to perform co-ordinated, goal-directed acts. True, the wording of section 23 does not cover such a case, and so it has been held by good case authority. ${ }^{53}$ But as has been argued previously, this form of insane automatism should be recognised as a residual common law defence of insane automatism under section 20 of the Crimes Act.

The third case selected for analysis is the High Court decision in $R v$ Bannin. ${ }^{54}$ It has been chosen because Fisher J's judgment provides a detailed, systematic and novel attempt to deal with cases of automatism and insanity. ${ }^{55}$ The appellant (D) was convicted of unlawfully entering a building with intent to commit a crime therein in breach of section 242 of the Crimes Act. D was a schoolboy who lived with his parents next door to

50 Phillips v The Queen [1969] 2 AC 130, 137 (HL) per Lord Diplock.

51 See also the main text accompanying note 10 above.

52 S Odgers "Contemporary Provocation Law - Is Substantially Impaired Self-control Enough?" in S Yeo (ed) Partial Excuses to Murder (Sydney, The Federation Press, 1991) 103.

$53 R v$ Burr [1969] NZLR 736, 748 (CA) per Turner J; Attorney-General for the State of South Australia v Brown [1960] AC 432, 449-450 (HL) per Lord Tucker.

$54 \quad R v$ Bannin [1991] 2 NZLR 237 (HC).

55 Fisher J's approach was applied in the District Court case of Police v H [1997] DCR 520. 
the complainant (V). D had entered V's home silently through an open door, walked into the kitchen and grasped $\mathrm{V}$ from behind, putting one hand on her breast. When $\mathrm{V}$ screamed at him, saying, "Get away from me, I'm telling your father" D looked alarmed and said "No, please don't do that. I'm going. I'm going" and left immediately. At the trial, expert evidence was tendered showing that, when the incident occurred, D was experiencing the intermediate stage of an episode of neurological disorder known as Kleine-Levin syndrome. The symptoms of this stage include an impaired state of consciousness, full or partial memory loss and inappropriate sexual behaviour. The trial judge excluded D's submission of automatism following the expert witness' evidence that automatism was confined to cases of epilepsy alone.

On appeal, Fisher J correctly held that the trial judge had erroneously abdicated his function of categorising D's mental disorder in legal terms. Fisher J then proceeded to devise a detailed and systematic approach to resolving cases where mental abnormality was relied upon to support several distinct legal defences. According to this approach, automatism was not given a preconceived definition but was dealt with under the issue of whether the defendant had the capacity to satisfy what the learned judge called the "mental elements" of the crime in question. These mental elements included both the requirement that the defendant's conduct was "conscious and voluntary"56 as well as "any mens rea of the crime charged". ${ }^{57}$ As stated by Fisher J. ${ }^{58}$

In my view, the true foundation for automatism lies in the mental elements of the particular crime with which the accused is charged. The physical ingredients of the crime must be voluntarily performed (traditionally the 'actus reus') and there must also be those additional mental requirements of knowledge, belief, purpose, intention and/or recklessness necessary to complete the crime (traditionally the 'mens rea'). If the accused lacks the capacity to form any one of the mental elements necessary to the crime charged, the prosecution must fail, whether or not other definitions of automatism apply. Equally, if the accused displays those mental elements, then in my view qualification for 'automatism' in any other sense will avail him naught.

This led his Honour to say that, when viewed in these terms, it was "immaterial whether the mental deficiency relates to the actus reus or the mens rea or both".59

$56 R$ v Bannin, above $\mathrm{n} 54,241$

$57 R v$ Bannin, above $\mathrm{n} 54,242$.

$58 R$ v Bannin, above $\mathrm{n} 54,250$

$59 R v$ Bannin, above $\mathrm{n} 54,250$. Contrast this with the description of voluntariness by Woodhouse J in Kilbride $v$ Lake [1962] NZLR 590, 593 (CA) as comprising a "mental stimulus required to promote acts ... [which] ... is entirely distinct from the mental element contained in the concept of mens 
Applying his approach to the facts in Bannin, Fisher J held that D had the capacity to voluntarily perform the conduct required of the crime charged "in the modest sense that it was preceded by a deliberate decision to act in that way". ${ }^{60}$ Likewise, in relation to the mens rea of the offence charged, he held that $\mathrm{D}$ had the capacity to form the relevant intent, namely, to enter V's house for the purpose of assaulting her. ${ }^{61}$ Accordingly, D could not be said to have committed the alleged crime in an automatic state. ${ }^{62}$

With regard to insane automatism, Fisher J reaffirmed the rulings in Burr and Bratty that such a form of incapacity was covered by the M'Naghten Rules or its statutory equivalent and nowhere else. ${ }^{63}$ This led him to make the following observations which are worth citing in full: 64 The common law does not recognise irresistible impulse as a defence ... An example is the man
who kills his wife because he is driven to do so by voices in his head. Significantly, even in
those cases the McNaughten [sic] rules are not addressed to the involuntariness of the conduct
as such. Rather, the focus is upon the capacity to understand what he was doing or that it was
wrong. The suggestion that the existing two limbs of the McNaughten [sic] rules should be
joined by a third - lack of capacity to resist compulsive urges - has from time to time been
argued but always rejected ... As was said in an explanatory note to the relevant cl 28(2)(b) in
the New Zealand Crimes Bill 1989 [that is, the Bill's provision on insanity]:

'The clause does not attempt to deal with the vexed question of volition. It seems that there are people who know what they are doing, know that it is wrong, but are unable, because of psychiatric disorder, to stop doing it. How the law can provide for these cases without opening the floodgates to those who simply give in to temptation is a question that has so far defied a practical answer.'

I submit that these observations contain both types of judicial misconceptions outlined earlier. As to the first misconception, Fisher J notes that questions as to the defendant's lack of capacity to understand what he or she is doing, or that it was wrong,

rea. The latter is the intention or the knowledge behind or accompanying the exercise of the will, while the former is simply the spark without which the actus reus cannot be produced at all".

$60 R v$ Bannin, above $\mathrm{n}$ 54, 255.

$61 \quad R v$ Bannin, above $\mathrm{n} 54,255$.

62 Ultimately, however, Fisher J held D not to be guilty of the offence charged. This was because the fact that $\mathrm{D}$ had the capacity to form intent did not mean that he necessarily formed that intent in fact. On the evidence before him, the prosecution had failed to prove that $\mathrm{D}$ had the intention to assault $\mathrm{V}$ at the time when he entered her house, as was required by the offence.

$63 R v$ Bannin, above n 54, 253-254.

$64 R v$ Bannin, above $n$ 54, 254. 
"are not addressed to the involuntariness of the conduct as such". This correctly recognises those mental incapacities for what they really are, namely, cognitive defects. ${ }^{65}$ As a subset of involuntariness, automatism is not concerned with these types of defects but with the volitional defect of a total incapacity to contain oneself. In this respect, the defence counsel's citation of Professor Gerald Orchard's comment that, "there must be an impairment of consciousness which involves the accused being deprived of the power to control his or her conduct or to choose to behave otherwise", 66 comes very close to expressing the true nature of automatism. It would have been even better had Orchard said that the accused was "totally deprived of the power to contain his or her conduct or to choose to behave otherwise".

This brings me to the second misconception by Fisher $\mathrm{J}$ in the above cited passage. While his Honour may have correctly noted that the wording of section 23 of the Crimes Act (largely embodying the M'Naghten Rules) does not recognise irresistible impulse, he failed to consider whether such a defect (being volitional as opposed to cognitive) might be recognised as a residual common law defence under section 20 of the Act. Furthermore, Fisher J's apparent endorsement of the explanatory note accompanying clause 28(2)(b) of the Crimes Bill 1989 overlooks (as the authors of the Bill also appear to have done) the fact that what is contemplated here is a total, as opposed to a partial, incapacity to resist. Contrary to the concern expressed in the explanatory note, expert witnesses should be able to clearly differentiate between persons who completely lacked the ability to resist the urge to commit the criminal behaviour in question from others who merely gave in to the temptation to do so. This oversight was also repeated when Fisher $\mathrm{J}$ stated that diminished responsibility is not a defence known to New Zealand law. ${ }^{67}$ That may be correct insofar as our Crimes Act does not have a provision such as the one under the Criminal Code of Queensland which reduces a charge of murder to manslaughter for those defendants who had suffered an abnormality of mind so as to impair their capacity to control their conduct. ${ }^{68}$ However, what is contemplated are cases

$65 R v$ Burr [1969] NZLR 736, 745 (CA) and cited with approval by Fisher $\mathrm{J}$ in $R v$ Bannin, above $\mathrm{n}$ 54, 254.

66 Orchard, above n $5,42$.

$67 R v$ Bannin, above $\mathrm{n} 54,243$.

68 Section 304A(1) reads: "When a person who unlawfully kills another under circumstances which, but for the provisions of this section, would constitute ... murder, is at the time of doing the act or making the omission which causes death in such a state of abnormality of mind (whether arising from a condition of arrested or retarded development of mind or inherent causes or induced by disease or injury) as substantially to impair his capacity to understand what he is doing, or his capacity to control his actions, or his capacity to know that he ought not to do the act or make the omission, he is guilty of manslaughter only." 
where defendants were totally (as opposed to partially) incapable of controlling their behaviour. ${ }^{69}$ I submit that there is ample justification, on grounds of justice and practicality, for such cases to be recognised as an instance of insane automatism under section 20 of the Crimes Act.

In spite of the criticisms made about Fisher J's approach, the outcome of the case would probably have been the same even if the correct law had been applied. D was clearly capable of resisting his urge to assault $\mathrm{V}$ as evinced by his immediate departure from V's house once she had screamed at him. Consequently, he was not in an automatic state at the time, which was the conclusion reached by Fisher J via a different and contentious route.

In sum, Fisher J's suggested treatment of automatism in Bannin confuses more than it clarifies. In proposing that automatism can arise whenever a defendant lacked the capacity to form the mens rea of the crime in question, his Honour may be criticised for making involuntariness a concept which can vary according to the mens rea requirement of each particular crime. ${ }^{70}$ The correct position is that involuntariness, and its subset of automatism, is concerned solely with the defendant's criminal responsibility for the actus reus and not with the capacity to meet the mens rea requirements. Contrary to Fisher J's view, any inquiry into automatism should begin with a preconceived definition of that concept which, it is submitted, is the total inability to contain one's conduct.

\section{THE WAY FORWARD}

The preceding discussion has produced certain propositions, the adoption of which, either by the courts or the legislature, will do much to rectify the current confusing state of the law on involuntariness, automatism and insanity. The propositions are that:

- Involuntariness and its subset, automatism, should be defined as a complete lack of capacity to contain one's conduct. This definition recognises that a defendant may have manifested deliberative functions of the mind including an intention to commit the crime charged, and still have performed the proscribed conduct involuntarily.

- Unconsciousness or impaired consciousness is not essential for a state of automatism to exist. Evidence of unconsciousness or impaired consciousness is

69 See Milloy (1991) 54 A Crim R 340 (Crim CA Qld) for a good example of a case where this distinction was made. See also D O'Connor and P Fairall Criminal Defences (3 ed, Butterworths, Sydney, 1996) 305.

70 Simester and Brookbanks, above n 20, 71. 
relevant, not because it is essential to a finding of automatism, but to show that the defendant's conduct was involuntary.

- A complete lack of capacity to contain one's conduct is distinguishable from the partial loss of self-control contemplated by the defence of provocation.

- A complete lack of capacity to contain one's conduct is also distinguishable from a partial lack of self-control contemplated by the defence of diminished responsibility recognised in some overseas criminal jurisdictions.

- A complete lack of capacity to contain one's conduct due to a disease of the mind should be legally recognised as a type of insane automatism. Until such time as section 23 of the Crimes Act is amended to include this type of case, the courts should do so by resorting to section 20 of the Act.

Recognition of these propositions will make cases of automatism and insanity more comprehensible and easier to resolve, without opening the floodgates to a cascade of automatism claims. It will be the rare few whose mental abnormality would be such as to result in a total inability to contain their behaviour. Even where that was the case, the most likely outcome would be the special verdict rather than an unqualified acquittal. 